\title{
A Cautious Defense of Intellectual Oligopoly With Fringe Competition ${ }^{1}$
}

\author{
Mark A. Lemley ${ }^{2}$
}

Michele Boldrin and David Levine offer a strong attack on intellectual property (IP), which they call "intellectual monopoly." ${ }^{3}$ In their view, IP is not necessary to encourage invention or creation. Quite the contrary, they argue that we get innovation from competition, not monopoly. Further, because monopoly imposes well-recognized social costs, we are better off without it if it doesn't in fact spur new innovation.

Boldrin and Levine make a plausible case on their own terms. Nonetheless, I think their terms are misleading. IP rights are rarely if ever "intellectual monopolies." Most patents, to say nothing of most copyrights, create no economic rents. ${ }^{4}$ Indeed, most patents are abandoned for failure to pay maintenance fees amounting to no more than a few thousand dollars. ${ }^{5}$ I may have the right to prevent anyone else from selling a "thumb-wrestling ring with stabilizing handle," ${ }^{6}$ but it isn't meaningful to talk about my having a "monopoly" over thumbwrestling rings with stabilizing handles. There is no economic market limited to thumbwrestling rings. Similarly, and with even more confidence, we can say that even quite successful books, music and movies do not define or dominate any economic market. Stephenie Meyer may be a popular author, but the price she charges for her books is the same

1 (c) 2009 Mark A. Lemley.

2 William H. Neukom Professor, Stanford Law School; partner, Durie Tangri LLP, San Francisco, California. Thanks to Rose Hagan, David McGowan, and two anonymous reviewers for comments.

3 Michele Boldrin \& David K. Levine, Against Intellectual Monopoly (2008).

4 For discussion, see, e.g., Illinois Tool Works, Inc. v. Independent Ink, Inc., 547 U.S. 28 (2006); 1 Herbert Hovenkamp et al., IP and Antitrust $\S 4.2$.

5 Kimberly A. Moore, Worthless Patents, 20 Berkeley Tech. L.J. 1521 (2005).

6 U.S. Patent No. 4,998,724. Or see a recent episode of "Chuck" featuring the ring. 
as the price every other author charges. The existence of IP rights allows a certain amount of market segmentation - I can write a book somewhat like Stephanie Meyer's, but I can't just copy Meyer's - and therefore allows virtually all creators to charge a price above the marginal cost of copying, which approaches zero. ${ }^{7}$ But it doesn't create a monopoly.

What this means is that we can't assume that IP rights generally impose deadweight losses on society. They cause deviation from atomistic, perfect competition, but they don't cause monopoly pricing. With a small number of exceptions, therefore, they don't cause the social harms Boldrin and Levine correctly associate with monopoly pricing. Some patents, and perhaps one or two copyrights, do in fact confer power in a relevant economic market. And we should pay attention to those. But it is a very large exaggeration to say that patents and copyrights are intellectual monopolies.

More significant is Boldrin and Levine's claim that competition, not monopoly, drives innovation. If this is right, we wouldn't need IP rights even if they were costless. I am sympathetic to the idea that competition is an important driver of innovation. ${ }^{8}$ But as I suggest below, I think Boldrin and Levine overstate the case for competitive innovation and understate the case for innovation driven by either market power or the prospect of acquiring market

7 See Christopher S. Yoo, Copyright and Product Differentiation, 79 N.Y.U. L. Rev. 212 (2004).

8 See, e.g., Mark A. Lemley, A New Balance Between IP and Antitrust, 13 Sw. J. L. \& Trade Ams. 237 (2007); Jonathan B. Baker, Beyond Schumpeter v. Arrow: How Antitrust Fosters Innovation, 74 Antitrust L.J. 575 (2007). On the relative value of innovation and static competition, see, e.g., Robert M. Solow, $A$ Contribution to the Theory of Economic Growth, 70 Q.J. Econ. 65 (1956) (attributing nearly 90\% of GNP growth in the U.S. to technological change rather than labor and capital improvements); James Bessen, More Machines or Better Machines? (working paper 2009) (studying the $19^{\text {th }}$ Century cotton weaving industry and finding the same); Jonathan B. Baker, "Dynamic Competition" Does Not Excuse Monopolization at 4 (working paper 2008) ("the push of competition generally spurs innovation more than the pull of monopoly"). 
power through patent. In the debate between Ken Arrow and Joseph Schumpeter, ${ }^{9}$ I tend to be an Arrowhead, not a Schumpeterian: I agree that competition often drives innovation and that monopoly often inhibits it. But often is not always, and the fact that in some circumstances market exclusivity promotes innovation counsels against a blanket condemnation of IP. ${ }^{10}$

The analysis of the wisdom of IP rights is complicated by the fact that innovation - and IP rights - work differently in different industries. As Dan Burk and I have argued, the rules appropriate for some industries work poorly in others. ${ }^{11}$ The classic theory of patent law arguably works poorly in the information technology industries for a variety of reasons that have been explained elsewhere, ${ }^{12}$ and that Boldrin and Levine echo. ${ }^{13}$ Innovators in the IT industries tend to use patents defensively, to protect themselves against suit, rather than relying on exclusivity and affirmative enforcement of IP rights. By contrast, the pharmaceutical, biotechnology, and medical devices industries depend critically on the enforcement of patents

9 Compare Kenneth Arrow, Economic Welfare and the Allocation of Resources for Invention, in The rate and Direction of Inventive Activity: Economic and Social Factors (1962) with Joseph Schumpeter, Capitalism, Socialism, and Democracy (1943).

10 Boldrin and Levine ask - presumably rhetorically - "how many industries can you mention where the mechanism described in the Schumpeterian model has been at work, with innovators frequently supplanting the incumbent monopolist, becoming a monopolist in turn, to be killed shortly after by yet another innovator?" Boldrin \& Levine, supra note __, at 170-71. Presumably the reader is intended, after a moment's reflection, to answer "well, gosh, none." In fact, however, a moment's reflection reveals quite a few. Off the top of my head, they include computer hardware (bought an IBM computer lately?), video games (it's Atari, no wait it's Nintendo, no wait it's Sega, no wait it's Sony, no wait it's Microsoft, oops, it's Sony a second time, but here comes Nintendo again), search engines (Altavista, then Excite, then Yahoo!, then Google), statins (where the prescribed drug of choice seems to vary year by year), and cell phones (Motorola StarTac anyone?). Remember, I am not a Schumpeterian: I don't think we should passively accept monopoly in the hopes that it will always or even usually sow the seeds of its own destruction. But Boldrin and Levine's claim that it never happens just won't fly.

11 Dan L. Burk \& Mark A. Lemley, The Patent Crisis and How the Courts Can Solve It (2009).

12 See, e.g., James Bessen \& Michael J. Meurer, Patent Failure: How Judges, Lawyers and Bureaucrats Put Innovation at Risk (2008).

13 Boldrin \& Levine, supra note _, at 72-78. 
to obtain at least partial market exclusivity. ${ }^{14}$ Similarly, commercialization-based theories of patents that focus on the purported need for exclusivity to produce and market the invention rather than to invent it ${ }^{15}$ also seem to carry more weight in the pharmaceutical industry, burdened by government regulation of entry, than in other industries in which commercialization is easier. ${ }^{16}$

We see similar divisions in copyright, though they don't divide as cleanly by industry. Significant sectors of the computer software industry have effectively abandoned copyright protection, using the copyright law only to ensure the continued openness of open source software. ${ }^{17}$ At the same time, other software developers rely heavily on copyright protection to prevent counterfeiting. In other industries, the importance of strong copyright protection depends on the economics of creativity in that industry. It is fairly cheap to produce music, for instance, so that - the vehement effort to expand music copyrights notwithstanding - we might well get significant new music even absent copyright protection. By contrast, blockbuster movies often require the investment of hundreds of millions of dollars, something that seems unlikely without some prospect of recouping that investment. That doesn't mean we would get no movies at all; the outpouring of creativity occasioned by YouTube makes it clear that people want to create, and will do so even absent any realistic prospect of making money by doing so.

14 Burk \& Lemley, supra note _, at ch. 4.

15 See, e.g., Edmund W. Kitch, The Nature and Function of the Patent System, 20 J. L. \& Econ. 265 (1977).

16 See, e.g., Mark A. Lemley, Ex Ante Versus Ex Post Justifications for Intellectual Property, 71 U. Chi. L. Rev. 129 (2004).

17 For analyses of open source peer production, see, e.g., Yochai Benkler, The Wealth of Networks (2006); Yochai Benkler, Coase's Penguin, or Linux and the Nature of the Firm, 112 Yale L.J. 369 (2002); David McGowan, Legal Implications of Open Source Software, 2001 U. III. L. Rev. 241. 
But the movies that would be created absent copyright protection won't include high-budget films like The Lord of the Rings. ${ }^{18}$

The fundamental question dividing these technologies and industries involves appropriability. Appropriability - the ability of the creator to capture rents sufficient to pay back the fixed cost investment of creation - is itself a function of both a number of different factors. Among those factors are the fixed cost of creation, the cost of imitation, and the availability of other returns than those provided by IP law. Boldrin and Levine correctly point out that a creator doesn't need to capture the full social value of their inventions; in fact, we don't want them to. ${ }^{19}$ They also correctly identify a number of mechanisms other than IP that companies can and do use to appropriate returns, including first-mover advantage, learning externalities, prizes, and complementary products. ${ }^{20}$ To this list we might reasonably add peer recognition, network effects, personal drive, government or private sponsorship, and brand identification. $^{21}$ There is no question that these appropriation mechanisms provide some incentive to creators, and that in some cases they provide enough incentive to drive creation. Similarly, Boldrin and Levine point to particular examples in which imitation is costly and timeconsuming, though notably that is in part because of other IP rights - trade secrets - that they don't criticize. ${ }^{22}$ But pointing to examples where IP isn't necessary is not sufficient to support

18 Perhaps we shouldn't care - Glynn Lunney has argued that copyright prompts inefficient overinvestment in gala works. Glynn S. Lunney, Jr., Reexamining Copyright's Incentives-Access Paradigm, 49 Vand. L. Rev. 483 (1996). But the market is surely able to punish those who overinvest in expensive films, as long as cheap films are around to challenge them.

19 Boldrin \& Levine, supra note _, at 160-66; Brett M. Frischmann \& Mark A. Lemley, Spillovers, 107

Colum. L. Rev. 257 (2007).

20 Boldrin \& Levine, supra note _, at 130-45.

21 Boldin and Levine do not object to trademark law.

22 Boldrin \& Levine, supra note _, at 161-66. 
the Boldrin-Levine thesis. Their thesis is that all innovation and creation - or at least all innovation and creation we want to have - will be motivated by these alternative mechanisms. ${ }^{23}$ To evaluate that implicit claim, we need to know exactly how much money the average inventor needs to make in order to break even. ${ }^{24}$ That in turn is a function of the ratio between the cost of creation and the cost and delay associated with imitation. If it's easy to create, and it is relatively hard to copy, first mover advantages may well be sufficient to ensure returns to creators. But if innovation is costly and time-consuming, and if copying is easy, the likelihood of recoupment is much less. One way to distinguish the industries that rely heavily on patent law from those that don't is that the patent-reliant industries face significant innovation costs, in part because of the way innovation works in those industries but in

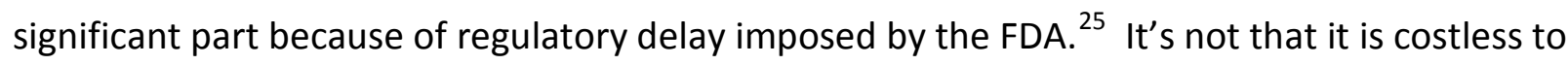
bring a generic drug to market, but that the ratio of innovator cost to imitator cost is too high to rely on first mover or trademark advantages. ${ }^{26}$

${ }^{23}$ The closest they come to making this case is in chapter 8 , discussing the inconclusive-but-notpromising results of economic studies of the role of patents. Unfortunately, social science is hard. We don't get many natural experiments. And most of the natural "experiments" conducted on the patent system involve national variations in patent rules over time. Those experiments contain a fatal flaw: the expected return from an invention is based on its global sales, not national sales. As a result, it doesn't make sense to say, as Boldrin and Levine do in talking about the pharmaceutical industry, that "crosscountry variations in patent protection of medical products should have had a dramatic impact on national pharmaceutical industries." Boldrin \& Levine, supra note _, at 218, 232. National differences in patent laws should affect the price and quantity of drugs sold in those countries, but the worldwide sales of a pharmaceutical patented everywhere except Switzerland should be the same whether the inventor is Swiss or not.

24 Boldrin and Levine rightly point out that it is the average expected return, not the actual ex post return, that matters. Id. at 130-34.

25 See, e.g., William E. Ridgway, Realizing Two-tiered Innovation Policy Through Drug Regulation, 58

Stan. L. Rev. 1221 (2006); Rebecca S. Eisenberg, The Shifting Functional Balance of Patents and Drug Regulation, 19 Health Aff. 119, 123 (2001).

26 Boldrin and Levine assert that we didn't have or need patent protection for most of the critical advances in medicine. But most of the advances they cite weren't drugs. And when they do turn to 
Focusing on the ratio of creation to imitation cost also enables us to pay attention to how the need for IP rights might change over time. Advances in technology can make it both easier to create and distribute original works and easier to copy those works. Technology has made it much easier to produce and distribute new music than ever before. Accordingly, it has made record company intermediaries - the traditional beneficiaries of music copyright - less and less relevant. At the same time, technology has made illegal copying cheap and easy, taking it out of the province of commercial counterfeiters and making it possible for everyone to infringe music copyrights. ${ }^{27}$ As a result, some argue (focusing on the cost of innovation) that we don't need music copyright in the new digital environment, while others argue (focusing on the cost of imitation) that it needs to be strengthened. Each side is focused on one part of the fraction; to get the right answer, we need to pay attention to the whole fraction. Similarly, scholars have disputed whether fashion design should be brought within the copyright system. ${ }^{28}$ The question is once again complicated, because technology has both reduced the cost of design and also reduced the cost of imitation. ${ }^{29}$ And even the pharmaceutical industry -

drugs, they get the facts wrong - for example, by claiming that aspirin wasn't patented. Boldrin \& Levine, supra note _, at 229. Contra Diarmuid Jeffreys. Aspirin: The Remarkable Story of a Wonder Drug 77-80 (2005) (documenting the patenting and successful enforcement of aspirin in the U.S.). Boldrin and Levine may be relying on the fact that aspirin was not patented in Germany, where it was invented. But as I noted above, the market for inventions is global, and so is the calculus of risk and reward. The fact that even in the $19^{\text {th }}$ Century Bayer was careful to obtain patent protection in the U.S. and the U.K. suggests that they were certainly not indifferent to the patentability of aspirin.

27 See Boldrin \& Levine, supra note _, at 173.

28 Compare Kal Raustiala \& Christopher Sprigman, The Piracy Paradox: Innovation and Intellectual Property in Fashion Design, 92 Va. L. Rev. 1687 (2006) (arguing that fashion design flourishes in the absence of copyright protection) with C. Scott Hemphill \& Jeannie Suk, The Law, Culture, and Economics of Fashion, 61 Stan. L. Rev. 1147 (2009) (arguing that decreases in the cost of imitation in fashion are beginning to erode incentives for designers).

29 Boldrin and Levine object that no one knows what inventions or creations to copy unless they wait to see which ones are successful, and by that time the inventor has recouped investment. Boldrin \& Levine, supra note _, at 137-45. This is a fair point, but it only works sometimes. If an unknown 
the poster child for strong patent protection - presents a tougher case than one might suppose, ${ }^{30}$ because the high costs of bringing a new drug to market are counterbalanced by the extraordinary legal power we confer on pharmaceutical inventors by combining patent protection with the exclusivity of the regulatory state. ${ }^{31}$

Bottom line: Do we need monopoly to drive appropriability? Perhaps occasionally, but generally not. But remember that IP rights aren't generally monopolies. Perhaps occasionally, but generally not. So, while we don't need "intellectual monopoly," what IP law gives us is more akin to "intellectual oligopoly" - product-differentiated competition among a limited number of market players - and the more modest boost in appropriability provided by that product differentiation may be desirable in some circumstances. ${ }^{32}$ To be clear, oligopoly is not desirable in and of itself, but only to the extent Schumpeter is right that perfect competition drives prices too quickly to marginal cost and prevents recoupment of fixed cost investments.

Further, IP rights may facilitate start-ups in some circumstances by giving an inventor who doesn't have the capital to enter the market at scale some breathing room. The fact that I can prevent exact duplication of my new idea by a large established player in my industry may give me the time to get established in that industry. It may also facilitate capital investment,

creator designs a new dress, it may not be quickly copied. But if the dress is a hit, imitators will rush to copy the next dress from the same designer. So Boldrin and Levine's argument might bring us new creation by unknown creators, but it won't give any margin to new innovation by established creators.

30 See Boldrin \& Levine, supra note _, ch. 9.

31 See Ridgway, supra note

32 Curiously, Boldrin and Levine criticize the pharmaceutical industry for spending so much R\&D money on "me-too" drugs rather than drugs that open entirely new markets. Boldrin \& Levine, supra note _, at 226. They deride it as an "anemic and pathetic version" of market competition, id. at 231. But that's precisely the sort of competitive, as opposed to Schumpeterian, innovation that they purport to want to encourage by eliminating IP rights. Competitive innovation is in general more likely to benefit society than pure copying. 
since venture capitalists often look at IP portfolios in deciding whether to invest in a new company. ${ }^{33}$ Thus, IP rights may facilitate not just oligopoly, but what is arguably the most important form of competition - the "creative destruction" of a new disruptive technology. ${ }^{34}$ And while I agree with Boldrin and Levine that competition is valuable, there seems little question that innovation is more valuable still. (Ask yourself whether you'd rather have a $\$ 200$ iPhone, despite being stuck with a lousy cellular carrier, or a really, really cheap 1990s-era brick-shaped cell phone). So IP rights offer the promise of promoting not just intellectual oligopoly but also fringe competition by new technologies.

That sounds like a pretty good deal. Why, then, call this a "cautious defense"? The answer is two-fold. First, Boldrin and Levine are correct that we will get some innovation in many industries, and even the same level of innovation in some industries, without IP protection. And IP rights are not costless. They not only impose static inefficiencies in the forms of reduced output and higher prices, but can interfere with innovation as well as promote it by raising input costs and creating the potential for holdup. Monopolists, as Boldrin and Levine correctly point out, are frequently stupid. ${ }^{35}$ We don't want them running our economy, any more than we want Soviet central planners doing so. So in an ideal world, we would give IP protection only in those circumstances in which we need it. ${ }^{36}$ And if we could tell

33 See Mark A. Lemley, Reconceiving Patents in the Age of Venture Capital, 4 J. Sm. \& Emerging Bus. L. 137 (2000); Clarisa Long, Patent Signals, 69 U. Chi. L. Rev. 625 (2002). John Allison and Ronald Mann find a significant positive relationship between startup patents and the success of those firms, though it is not clear which way causation runs in that story. John R. Allison \& Ronald J. Mann, Software Patents, Incumbents, and Entry, 85 Tex. L. Rev. 1579 (2007).

34 Schumpeter, supra note _..

35 Boldrin \& Levine, supra note _, at 87-90.

36 As Larry Lessig puts it, "sufficient incentive is something less than perfect control." Lawrence Lessig, Intellectual Property and Code, 11 St. John's J. Legal Comm. 635, 638 (1996). 
in advance what those circumstances were, we would adjust policy accordingly. But for the most part, we can't. The need for IP-driven appropriability varies by industry, within industry by technology, within technology by particular invention and particular inventor, and even then may vary over time. We sometimes do carve particular pieces out of the IP regime: we don't give copyright protection to cooking or fashion design, and we don't give patents to abstract scientific principles or laws of nature. But for most types of invention and creation we just can't be confident that IP isn't driving at least some innovation. The result is an educated guess that, on balance, IP protection will give us more benefit in the industries in which it spurs competitive innovation and fringe competition than the harm it causes in raising prices and constraining downstream innovation. It is, as Mike Scherer puts it, "a system that, despite its manifest imperfections, has worked tolerably well." 37

Second, and more important, the fact that some stylized version of "IP" will promote innovation doesn't mean that our existing IP regime necessarily does so. Boldrin and Levine overreach in calling for the abolition of IP, but it is the case that some aspects of the IP regime inhibit rather than promote innovation. So their effort might more profitably be directed not to attacking IP as a whole, but in focusing on the subset of IP rules that seem unlikely to promote innovation. Some examples of rules that might be thought to inhibit rather than promote innovation follow: ${ }^{38}$

37 F.M. Scherer, Book Review, 20 Const. Pol. Econ. 94 (2009).

38 N.B. I am not suggesting that all these changes are desirable, only that these are the places where Boldrin and Levine might make their strongest stand. 
- There is no question that the duration of copyright is far too long. Whether or not retroactively extending copyright terms is constitutional, ${ }^{39}$ it's a really terrible idea. It provides no new incentive to create, and it makes it harder to build on the works of others.

- Copyright law too often restricts not slavish imitation, but a defendant's own creative works that use small amounts of the plaintiff's creativity, whether in music sampling, satire, collage, or backgrounds in movies and television. Not only are these uses unlikely to interfere with any expected copyright owner incentive, but enforcement of copyright against them raises the cost of the defendant's creativity and the prospect of having that creativity enjoined or held up.

- Indirect infringement rules in copyright may reach too broadly, shutting down "dual-use" technologies that have many legitimate uses as well as being usable for infringement. Doing so stifles innovation in media technologies in the service of promoting creativity in copyright industries.

- In modern patent litigation the overwhelming majority ( $90 \%$ or more) of lawsuits are brought not against copiers, but against defendants who independently invented the technology in question. ${ }^{40}$ Whether or not you consider that a problem in itself, it certainly suggests that patent litigation is too often used for ends other than promoting technology transfer. And it suggests that there is an awful lot of near-simultaneous invention going on, something

39 Eldred v. Ashcroft, 537 U.S. 186 (2003). 
that might or might not be consistent with Boldrin and Levine's claim that we don't need patents to drive those inventions, ${ }^{41}$ and may mean we are overrewarding inventors who have made only a marginal social contribution by slightly accelerating the disclosure of an idea. ${ }^{42}$

- In some circumstances damages rather than an injunction may be the appropriate remedy for infringement of an IP right, particularly where an injunction would block legal as well as illegal activity. ${ }^{43}$ The Supreme Court decision in eBay v. MercExchange $e^{44}$ took an important step toward rationalizing the law of IP remedies by requiring that a plaintiff prove entitlement to an injunction on a case-by-case basis. But the benefits of a liability rule will be undone if the damages awarded under that rule are punitive, and both statutory

41 See Boldrin \& Levine, supra note _, at 202-208; Samson Vermont, Independent Invention As a Defense to Patent Infringement, 105 Mich. L. Rev. 475 (2006). Boldrin and Levine take this as evidence that "intellectual monopoly is absolutely not necessary for great inventions to take place." Boldrin \& Levine, supra note _, at 208. But I'm not so sure. Sometimes simultaneous invention will be the result of exogenous changes in circumstances that make the invention possible for anyone, where it wasn't before. But patent law, properly interpreted, shouldn't grant patents in those cases. See Mark A. Lemley, Should Patent Infringement Require Proof of Copying?, 105 Mich. L. Rev. 1525 (2007). And sometimes pure serendipity is at work. But sometimes simultaneous invention reflects not the ease of invention, but the fact of a "patent race." See John F. Duffy, Rethinking the Prospect Theory of Patents, 71 U. Chi. L. Rev. 435 (2004) (discussing the advantages of patent races). Without the lure of a patent, neither inventor may have been racing to be the first.

42 See Joseph E. Stiglitz, Economic Foundations of Intellectual Property Rights, 57 Duke L.J. 1693, 170607 (2008).

43 See, e.g., Mark A. Lemley \& Philip J. Weiser, Should Property or Liability Rules Govern Information?, 85 Tex. L Rev. 783 (2007).

44547 U.S. 388 (2006). 
damages in copyright law ${ }^{45}$ and current patent practice in setting reasonable royalties often overcompensates IP owners, ${ }^{46}$ leading to unintended deterrence.

- Antitrust law too often defers to claims of IP ownership, allowing IP owners to convert a weak right into a strong one or a narrow right into a broad one. ${ }^{47}$

My argument, then, is not that the existing IP regime gets the balance right; I don't think it does. Our IP regime should be more concerned with preventing rapid duplication, and less concerned with internalizing all social benefits or giving creators control over productive reuses, than it is today. Rather, the argument is that the right set of policies for encouraging innovation will probably include at least some IP in the mix - not because we want to encourage intellectual monopoly, but because we want to encourage dynamic competition.

17 U.S.C. § 504(c).

46 See, e.g., Mark A. Lemley, Distinguishing Lost Profits From Reasonable Royalties, _ Wm. \& Mary L. Rev. _ (forthcoming 2009); Brian J. Love, Patentee Overcompensation and the Entire Market Value Rule, 60 Stan. L. Rev. 263 (2007).

47 A notable example involves agreements by pharmaceutical companies to pay generics not to enter the market, preserving legal exclusivity of a weak patent. Despite the unquestionably anticompetitive nature of these agreements, courts have generally permitted them on the grounds that they must defer to the IP right in question. See, e.g., In re Ciprofloxacin Hydrochloride Antitrust Litig., 544 F.3d 1323 (Fed. Cir. 2008). For criticism, see, e.g., Herbert Hovenkamp et al. Anticompetitive Settlement of Intellectual Property Disputes, 87 Minn. L. Rev. 1719 (2003); C. Scott Hemphill, Paying for Delay: Pharmaceutical Patent Settlement as a Regulatory Design Problem, 81 N.Y.U. L. Rev. 1553 (2006). For detailed analysis of the complex relationship between IP and antitrust, see Hovenkamp et al., supra note 